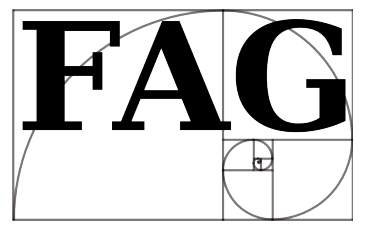

\title{
Odpowiedź na biochemiczny argument z projektu *
}

To, co sprawia, że uprawianie nauki jest tak emocjonującą działalnością, to jej rewolucyjny charakter. Gdy nauka posuwa się naprzód, zawsze istnieje możliwość, że jakiś badacz, pracujący w terenie lub przy stole laboratoryjnym, dokona odkrycia czy uzyska wynik doświadczalny, który całkowicie przekształci nasze pojmowanie przyrody. Historia nauki daje tak wiele przykładów takich odkryć, że pod wieloma względami praktyka naukowa faworyzuje małego człowieka, pojedynczego badacza, który może mieć klucz do następnego fundamentalnego postępu naukowego. Rzeczywiście, jeśli istnieje jakiś dogmat w nauce, to tylko taki, że w nauce nie ma dogmatów.

W praktyce oznacza to, że w nauce można wszystko zakwestionować. Czy możemy być pewni, że nic nie może być szybsze od prędkości światła? Czy jest możliwe, by informację genetyczną przenosiły białka, a nie DNA? Czy Einstein poprawnie sformułował ogólną teorię względności? Nigdy nie jest łatwo dokonać przewrotu w nauce, lecz praktyka naukowa wymaga jako największe przykazanie, żeby w nauce wszystko można było zakwestionować. Wszystko.

\footnotetext{
* Kenneth R. Miller, „Answering the Biochemical Argument from Design”, w: Neil A. Manson (ed.), God and Design: The Teleological Argument and Modern Science, Routledge, London 2003, s. 292-307. Z języka angielskiego za zgodą Autora przełożył Dariusz SAGAN. Recenzent: Grzegorz NowAK, Zakład Biochemii UMCS, Lublin.
} 
W 1996 roku Michael Behe wykonał śmiałe posunięcie zgodne z tą tradycją naukową, rzucając wyzwanie jednej z najbardziej użytecznych, produktywnych i fundamentalnych koncepcji w całej biologii teorii ewolucji Karola Darwina. Prowokacyjne twierdzenie Behe'ego, szczegółowo wyłożone w jego książce Darwin's Black Box [Czarna skrzynka Darwina] mówi, że bez względu na to, co jeszcze ewolucjonizm darwinowski może skutecznie wyjaśnić, nie jest w stanie wytłumaczyć biochemicznej złożoności żywej komórki. Jak wyraził to Behe: ,aby darwinowska teoria ewolucji była prawdziwa, musi wyjaśnić molekularną strukturę życia. Celem tej książki jest pokazanie, że ewolucjonizm darwinowski tego nie czyni”. ${ }^{1}$

Jak zobaczymy, argument Behe'ego skupia się na istnieniu złożonych mechanizmów molekularnych, znajdowanych we wszystkich żywych komórkach. Ewolucja nie mogłaby wytworzyć takich mechanizmów, dowodził, i dlatego muszą być one wytworami inteligentnego projektu. Jest to pogląd, który wyraził w innym miejscu swojej książki. Argument ten został podchwycony przez rozmaite grupy antyewolucyjne działające w USA i stał się głównym orężem ludzi argumentujących, że teoria „inteligentnego projektu” (ID) jako naukowa alternatywa dla darwinizmu zasługuje na to, aby nauczać jej na lekcjach nauk przyrodniczych. W tym krótkim przeglądzie proponuję sprawdzenie tej linii rozumowania. Przeanalizuję zarówno świadectwo naukowe na rzecz tego twierdzenia, jak i strukturę logiczną biochemicznego argumentu z projektu, a także postawię najbardziej podstawowe pytanie, jakie można zadać w stosunku do każdej hipotezy naukowej: czy zgadza się ona z faktami?

\footnotetext{
${ }^{1}$ Michael J. BehE, Darwin's Black Box: The Biochemical Challenge to Evolution, The Free Press, New York 1996, s. 24-25.
} 


\section{Wyjątkowe twierdzenie}

Od blisko półtora wieku jednym z klasycznych sposobów argumentowania przeciw ewolucjonizmowi było wskazywanie wyjątkowo złożonej i zawiłej struktury, którą potem kazano ewolucjoniście „wyewoluować"! Przykłady takich wyzwań obejmowały wszystko, od optycznych cudów ludzkiego oka do systemu obronnego chrząszcza kanoniera. Na pierwszy rzut oka przykłady Behe'ego wydają się pasować do tej tradycji. Jako przykłady maszynerii komórkowych, dla których nie istnieją wyjaśnienia ewolucyjne, podał rzęski i wici, wytwarzające ruch komórkowy, kaskadę białek powodujących krzepnięcie krwi, systemy kierujące białka w specyficzne miejsca w komórce, produkcję przeciwciał przez system immunologiczny oraz zawiłości procesów biosyntezy.

Zdaje on sobie jednak sprawę, że samo istnienie struktur i procesów, którym nie dano jeszcze stopniowego, darwinowskiego wyjaśnienia, nie dostarcza dowodu przeciwko ewolucjonizmowi. Krytycy ewolucjonizmu rzucali wcześniej takie wyzwania, uzyskując odwrotny skutek, gdy tylko nowe badania naukowe dostarczały właśnie tego świadectwa empirycznego, którego żądali. Sam Behe wypowiedział kiedyś podobne twierdzenie, gdy rzucił wyzwanie ewolucjonistom, by wytworzyli przejściowe skamieniałości łączące pierwsze wieloryby kopalne $\mathrm{z}$ ich domniemanymi lądowymi przodkami. ${ }^{2}$ Jak na ironię, pod koniec roku 1994, gdy opublikował on swoje wyzwanie, odkryto nie jeden, nie dwa, lecz trzy gatunki przejściowe między wielorybami a lądowymi ssakami z Eocenu. ${ }^{3}$

Biorąc pod uwagę, że zadaniem nauki jest dostarczanie i testowanie wyjaśnień, fakt, że istnieje kilka układów, na temat których - jak

\footnotetext{
${ }^{2}$ Michael J. BeHE, „Experimental support for regarding functional classes of proteins to be highly isolated from each other", w: J. Buell and V. Hearn (eds.), Darwinism: Science or Philosophy?, The Foundation for Thought and Ethics, Houston, Texas 1994, s. 61.

${ }^{3}$ S.J. Gould, „Hooking Leviathan by its past”, Natural History, May 1994, s. 8-15.
} 
dotąd - nie opublikowano wyjaśnień ewolucyjnych, to niewiele jak na argument przeciwko darwinizmowi. Znaczy to raczej, że owo pole dociekań jest nadal aktywne, witalne i przepełnione naukowymi wyzwaniami. Behe zdaje sobie $\mathrm{z}$ tego sprawę i dlatego jego zasadnicze twierdzenie o projekcie jest całkowicie odmienne. Całkiem poprawnie zaobserwował on, że nauka nie wyjaśniła procesu ewolucji wici bakteryjnej, ale następnie posuwa się krok dalej. Zgodnie z Behe'em, żadne takie wyjaśnienie nie jest nawet możliwe. Dlaczego? Dlatego, że wić posiada pewną charakterystykę, którą nazywa on „nieredukowalną złożonością":

Przez nieredukowalnie złożony rozumiem pojedynczy system, złożony z kilku dobrze dopasowanych, oddziałujących ze sobą części, które mają udział w pełnieniu podstawowej funkcji układu, a usunięcie jakiejkolwiek z tych części powoduje, że system przestaje sprawnie funkcjonować. ${ }^{4}$

Nieredukowalna złożoność jest kluczowa dla jego argumentu przeciwko darwinizmowi. Dlaczego? Ponieważ otwiera ona łańcuch rozumowania, który pozwala krytykowi ewolucjonizmu uzyskać wniosek o projekcie. Pozwala ona stwierdzić, że w zasadzie można odrzucić koncepcję ewolucyjnego powstania jakiejkolwiek złożonej struktury biochemicznej. Aby uczynić swój pogląd całkowicie jasnym, jako przykładu nieredukowalnej złożoności Behe użył pospolitego, mechanicznego urządzenia - pułapki na myszy:

Dobrym przykładem takiego systemu jest mechaniczna pułapka na myszy. [...] Działanie pułapki na myszy zależy od obecności wszystkich swoich pięciu składników; gdyby nie było sprężyny, to mysz nie zostałaby przyszpilona do podłoża; gdyby nie było podstawy, to pozostałe części rozpadłyby się i tak dalej. Działanie pułapki wymaga wszystkich części: nie możecie złapać kilku myszy przy pomocy samej podstawy, dodać sprężynę i złapać trochę więcej myszy, dodać drążek przytrzymujący i złapać ich jeszcze więcej. Wszystkie składniki

\footnotetext{
${ }^{4}$ Behe, Darwin's Black Box..., s. 39.
} 
muszą być na swoim miejscu, zanim jakakolwiek mysz zostanie złapana. Pułapka na myszy jest więc nieredukowalnie złożona. ${ }^{5}$

Skoro każda część pułapki na myszy musi być na swoim miejscu, zanim zacznie funkcjonować, to częściowe pułapki na myszy - te, którym brakuje jednej czy dwóch części - są bezużyteczne; nie możecie za ich pomocą złapać myszy. Gdy rozszerzymy tę analogię na nieredukowalnie złożone mechanizmy biochemiczne, to stwierdzimy, że one także nie pełnią żadnej funkcji, zanim zgromadzą się wszystkie ich części. Oznacza to, oczywiście, że dobór naturalny nie mógłby wytworzyć takich mechanizmów stopniowo, po jednej części naraz. Byłyby one niefunkcjonalne, zanim zgromadziłyby się wszystkie ich części, a dobór naturalny, który może wybierać tylko systemy funkcjonalne, nie miałby na czym pracować.

Behe wyraził to całkiem jasno:

Układu nieredukowalnie złożonego nie można bezpośrednio wytworzyć poprzez liczne, następujące po sobie, drobne przekształcenia układu będącego jego prekursorem, ponieważ każdy prekursor systemu nieredukowalnie złożonego, któremu brakuje jakiejś części, jest z definicji niefunkcjonalny. Skoro dobór naturalny może wybierać tylko takie układy, które już działają, to jeśli jakiegoś systemu biologicznego nie można wytworzyć stopniowo, musiał on powstać jako zintegrowana jednostka, w jednym pełnym skoku, aby dobór naturalny miał na co oddziaływać. ${ }^{6}$

W ujęciu Behe'ego sama ta obserwacja stanowi argument na rzecz projektu. Jeśli biochemicznej maszynerii komórki nie mógł wytwo-

\footnotetext{
${ }^{5}$ Michael J. BeHE, „Intelligent design theory as a tool for analyzing biochemical systems", w: W.A. Dembski (ed.) Mere Creation, InterVarsity Press, Downers Grove, Illinois 1998.

${ }^{6}$ Michael J. BEHE, „Evidence for intelligent design from biochemistry”, z mowy wygłoszonej 10 sierpnia 1996 na konferencji zorganizowanej przez Discovery Institute na temat „Bóg a kultura”. Dostępne na stronie internetowej Discovery Institute: www.discovery.org.
} 
rzyć dobór naturalny, to jest tylko jedna rozsądna alternatywa - została ona zaprojektowana przez jakiś inteligentny czynnik. Żeby nikt nie wątpił $\mathrm{w}$ jego twierdzenie o absolutnej niemożliwości wytworzenia takiej maszynerii przez ewolucję, Behe zapewnia swoich czytelników, że ogromna ilość traktującej o ewolucji literatury naukowej nie zawiera ani jednego przykładu, który by temu zaprzeczył:

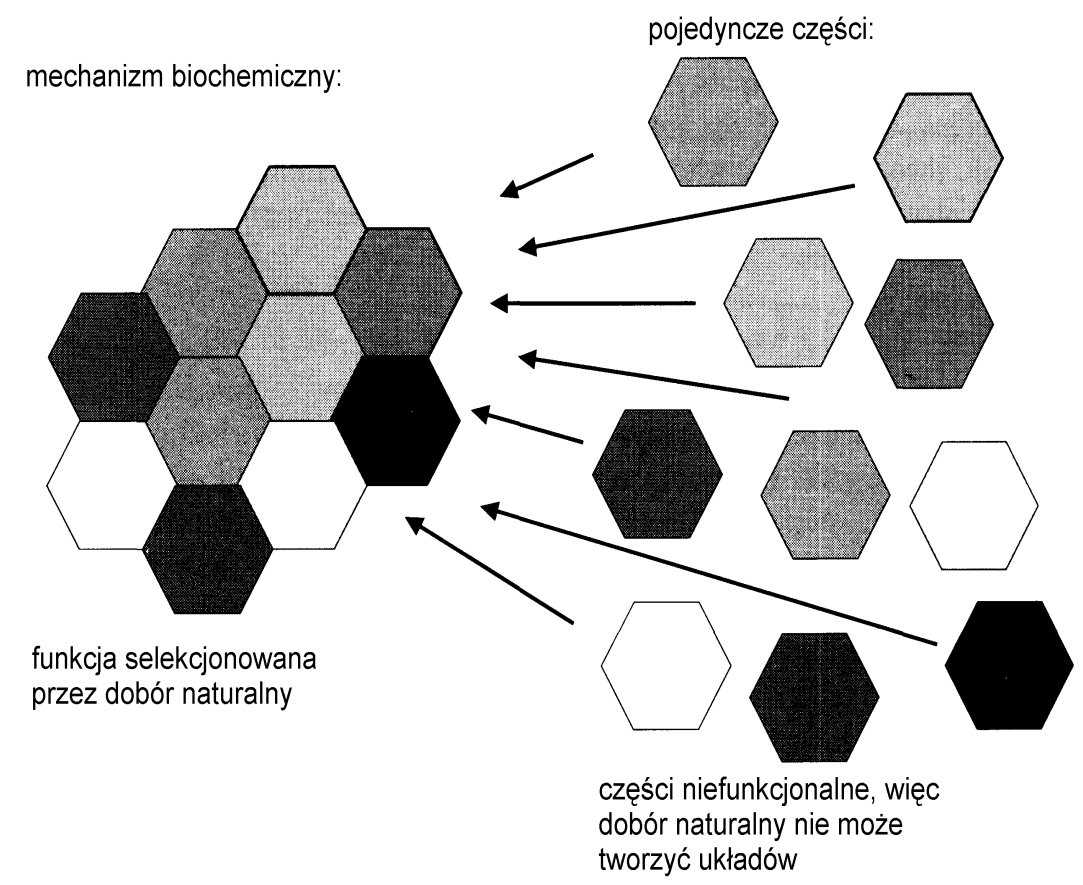

Rys. 1. Biochemiczny argument z projektu.

Uwaga: zgodnie $\mathrm{z}$ biochemicznym argumentem $\mathrm{z}$ projektu, dobór naturalny nie mógłby wytworzyć nieredukowalnie złożonego mechanizmu biochemicznego, ponieważ jego pojedyncze części nie pełnią, z definicji, żadnej podatnej na dobór funkcji.

Nie istnieje żadna publikacja w literaturze naukowej - w prestiżowych czasopismach, czasopismach specjalistycznych czy książkach - w której by opisywano, 
jak nastąpiła, czy nawet, jak mogłaby nastąpić, molekularna ewolucja jakiegokolwiek rzeczywistego złożonego systemu biochemicznego. ${ }^{7}$

Mocno powiedziane. Wielka siła argumentu Behe’ego opiera się na twierdzeniu, że w biochemicznej maszynerii żywej komórki odkrył on jakąś nową własność (nieredukowalną złożoność), która umożliwia odrzucenie, nawet w zasadzie, jakiejkolwiek możliwości, że mogłaby ją wytworzyć ewolucja. Następne pytanie, jakie powinniśmy zadać, jest proste - czy Behe ma rację?

\section{Warsztat Pana Darwina}

Jeśli argumenty Behe'ego brzmią dla kogoś znajomo, to słusznie. Są one lustrzanym odbiciem klasycznego „Argumentu z Projektu”, tak dobrze wyrażonego przez Williama Paleya blisko 200 lat temu w książce Natural Theology. Darwin dobrze znał ten argument i pisząc $\mathbf{O}$ powstawaniu gatunków specjalnie zatroszczył się o udzielenie odpowiedzi. W gruncie rzeczy Darwin odpowiedział, że ewolucja wytwarza złożone organy poprzez w pełni funkcjonalne, pośrednie etapy. Skoro dobór naturalny może faworyzować każdy pośredni etap, to i cały proces też może. Czy jest coś takiego w biochemii, co sprawiałoby, że odpowiedź Darwina mogłaby nie stosować się do wskazywanych przez Behe’ego systemów molekularnych?

Krótko mówiąc - nie.

W roku 1998 Siegfried Musser i Sunney Chan opisali ewolucyjny rozwój pompy protonowej oksydazy cytochromu c, złożonego, wieloczęściowego mechanizmu molekularnego, który odgrywa kluczową rolę $\mathrm{w}$ przemianie energii $\mathrm{w}$ komórce. W komórkach ludzkich pompa ta składa się z sześciu białek, z których każde jest konieczne dla właściwego jej funkcjonowania. Wydaje się ona do-

\footnotetext{
${ }^{7}$ BeHE, Darwin's Black Box..., s. 185.
} 
skonałym przykładem nieredukowalnej złożoności. Zabierz jedną część, a pompa nie będzie już pracować. A mimo to autorzy mogli stworzyć, w imponujących szczegółach, „drzewo ewolucyjne skonstruowane dzięki wyobrażeniu, że złożoność i wydajność oddechowa zwiększały się podczas procesu ewolucyjnego". ${ }^{8}$

Jak to możliwe? Gdybyście uwierzyli w zapewnienie Michaela Behe'ego, że mechanizmy biochemiczne są nieredukowalnie złożone, nie chcielibyście tego sprawdzać - $\mathrm{i}$ to jest prawdziwe naukowe niebezpieczeństwo jego idei. Musser i Chan sprawdzili to i zobaczyli, że dwa $z$ sześciu białek w pompie protonowej były całkiem podobne do enzymu bakteryjnego znanego jako kompleks cytochromów bo ${ }_{3}$. Czy może to oznaczać, że część pompy protonowej wyewoluowała z działającego kompleksu cytochromów $\mathrm{bo}_{3}$ ? Z pewnością - tak.

Ancestralny, dwuczęściowy kompleks cytochromów bo ${ }_{3}$ mógłby być w pełni funkcjonalny, choć w innym układzie, lecz ów układ w rzeczywistości pozwalałby doborowi naturalnemu na faworyzowanie jego ewolucji. Skąd pewność, że ta „połowa” pompy w ogóle byłaby użyteczna? Mamy ją dzięki odniesieniu się do współcześnie żyjących organizmów, które mają pełną, działającą wersję kompleksu cytochromów bo $_{3}$. Czy możemy użyć tego samego argumentu dla pozostałej części tej pompy? Cóż, okazuje się, że każda z głównych części pompy jest blisko związana $\mathrm{z}$ działającymi kompleksami proteinowymi, znajdującymi się w mikroorganizmach. Jak zaproponowali Musser i Chan, ewolucja składa złożone mechanizmy biochemiczne z mniejszych działających mechanizmów biochemicznych, które zostały przystosowane do pełnienia nowych funkcji. Wiele części złożonych mechanizmów biochemicznych składa się z mniejszych działających mechanizmów rozwiniętych przez dobór naturalny, jak to pokazuje rysunek 2 .

\footnotetext{
${ }^{8}$ S.M. Musser and S.I. Chan, „Evolution of the cytochrome c oxidase proton pump”, Journal of Molecular Evolution 1998, vol. 46, s. 517 [508-520].
} 
A co ze stwierdzeniem, że nigdzie nie ma żadnej publikacji opisującej, jak ,nastąpiła, czy nawet mogłaby nastąpić, molekularna ewolucja jakiegokolwiek rzeczywistego złożonego układu biochemicznego?" Po prostu jest ono nieprawdziwe.

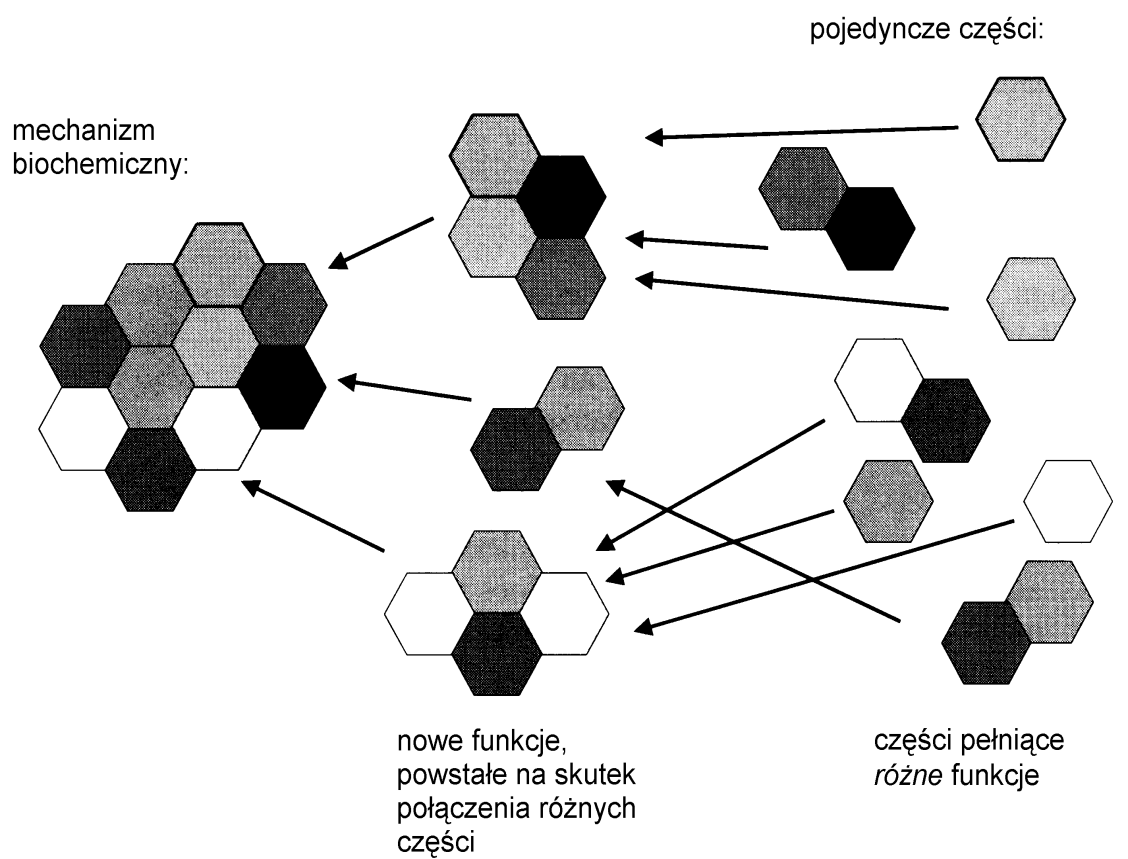

Rys. 2. Ewolucja mechanizmów biochemicznych.

Uwaga: darwinowskie ujęcie ewolucji złożonych mechanizmów molekularnych wymaga tego, aby ich pojedyncze części i składniki pełniły podatne na dobór naturalny funkcje.

W 1996 roku Enrique Melendez-Hevia i jego współpracownicy opublikowali w Journal of Molecular Evolution rozprawę zatytułowaną „The puzzle of the Krebs citric acid cycle: Assembling the pieces of chemically feasible reactions, and opportunism in the design of metabolic pathways during evolution” [,Zagadka cyklu kwasu cytrynowego (cyklu Krebsa): gromadzenie kawałków chemicznie wykonal- 
nych reakcji oraz oportunizm przy powstawaniu projektu procesów metabolicznych w trakcie ewolucji"]. ${ }^{9}$ Cykl Krebsa jest rzeczywisty, złożony i biochemiczny, a ta rozprawa ukazuje coś, co Behe uważa za niewykonalne, nawet w zasadzie - prezentuje ona możliwy model ewolucji cyklu Krebsa z prostszych systemów biochemicznych. Rozprawa ta, jak również późniejszy przegląd dokonany przez innych autorów, ${ }^{10}$ pokazuje, że schemat wskazany na rysunku 2 jest w pełni wystarczającym modelem dla wyjaśnienia biochemicznej złożoności.

Nie są to odizolowane przykłady. Ostatnio Martino Rizzotti opublikował serię szczegółowych hipotez opisujących stopniową ewolucję wielkiej różnorodności struktur komórkowych, łącznie z wicią bakteryjną i rzęską eukariotyczną. ${ }^{11}$ Nawet przez chwilę nie twierdzę, że wszystkie wyjaśnienia Rizzottiego stanowią ostatnie słowo na temat ewolucji tych struktur. Mimo tego przy bliższym sprawdzeniu twierdzenie, iż w literaturze brakuje takich wyjaśnień, traci rację bytu.

Wszystko to oczywiście oznacza, że dwa zasadnicze twierdzenia ruchu ID zostały obalone, mianowicie to, że nie można przedstawić darwinowskiego wyjaśnienia ewolucji złożonego układu biochemicznego oraz to, że w literaturze naukowej nie ukazują się rozprawy traktujące o tym. To pierwsze jest możliwe, a takie rozprawy istnieją.

\footnotetext{
${ }^{9}$ E. Melendez-Hevia, T.G. Waddell and M. Cascante, „The puzzle of the Krebs citric acid cycle: Assembling the pieces of chemically feasible reactions, and opportunism in the design of metabolic pathways during evolution", Journal of Molecular Evolution 1996, vol. 43, s. 293-303.

${ }^{10}$ M.A. Huynen, T. Dandekar and P. Bork, ,Variation and evolution of the citric acid cycle: A genomic perspective”, Trends in Microbiology 1999, vol. 7, s. 281-91.

${ }^{11}$ M. Rizzotтi, Early Evolution: From the Appearance of the First Cell to the First Modern Organisms, Birkhauser, Basel 2000.
} 


\section{Sedno sprawy}

Aby w pełni zbadać podstawy biochemicznego argumentu z projektu, powinniśmy dociec szczegółów pewnych struktur użytych właśnie w książce Behe’ego jako przykłady systemów nieredukowal nie złożonych. Jedną z nich jest rzęska eukariotyczna, zawiła, przypominająca bat struktura, która wytwarza ruch w tak różnych komórkach, jak sinice i ludzkie plemniki. A także,

Podobnie jak pułapka na myszy nie funkcjonuje, chyba że obecne są wszystkie jej części składowe, ruch rzęskowy po prostu nie istnieje, gdy brakuje mikrotubul, połączeń i silników. Możemy więc wysunąć wniosek, że rzęska jest nieredukowalnie złożona. ${ }^{12}$

Czy pamiętacie stwierdzenie Behe'ego, że usunięcie choćby jednej części z układu nieredukowalnie złożonego powoduje, iż przestaje on działać? Rzęska daje nam doskonałą okazję sprawdzenia tego założenia. Jeśli jest ono słuszne, to nigdzie w przyrodzie nie powinniśmy znaleźć przykładów funkcjonalnych rzęsek, którym brakuje podstawowych części. Niefortunnie dla tego argumentu, tak się nie dzieje. Przyroda przedstawia wiele przykładów w pełni funkcjonalnych rzęsek, którym brakuje kluczowych części. Jednym z najistotniejszych jest wić plemnika w kształcie węgorza (rysunek 3), której brakuje co najmniej trzech części normalnie występujących w rzęsce: centralnego dubletu, centralnych szprych i zewnętrznego ramienia dyneinowego. ${ }^{13}$

Pozostaje nam rozważyć dwie sprawy. Po pierwsze, istnieje duża różnorodność systemów ruchowych, którym brakuje części tej rzekomo nieredukowalnie złożonej struktury. Po drugie, biologowie

\footnotetext{
${ }^{12}$ Behe, Darwin's Black Box..., s. 65.

${ }^{13}$ D.M. Wooley, „Studies on the eel sperm flagellum”, Journal of Cell Science 1997, vol. 110, s. 85-94.
} 
od dawna wiedzą, że główne składniki rzęski, łącznie z białkami: tubuliną, dyneiną i aktyną, pełnią odmienne, nie związane z ruchem komórkowym funkcje gdzie indziej w komórce.

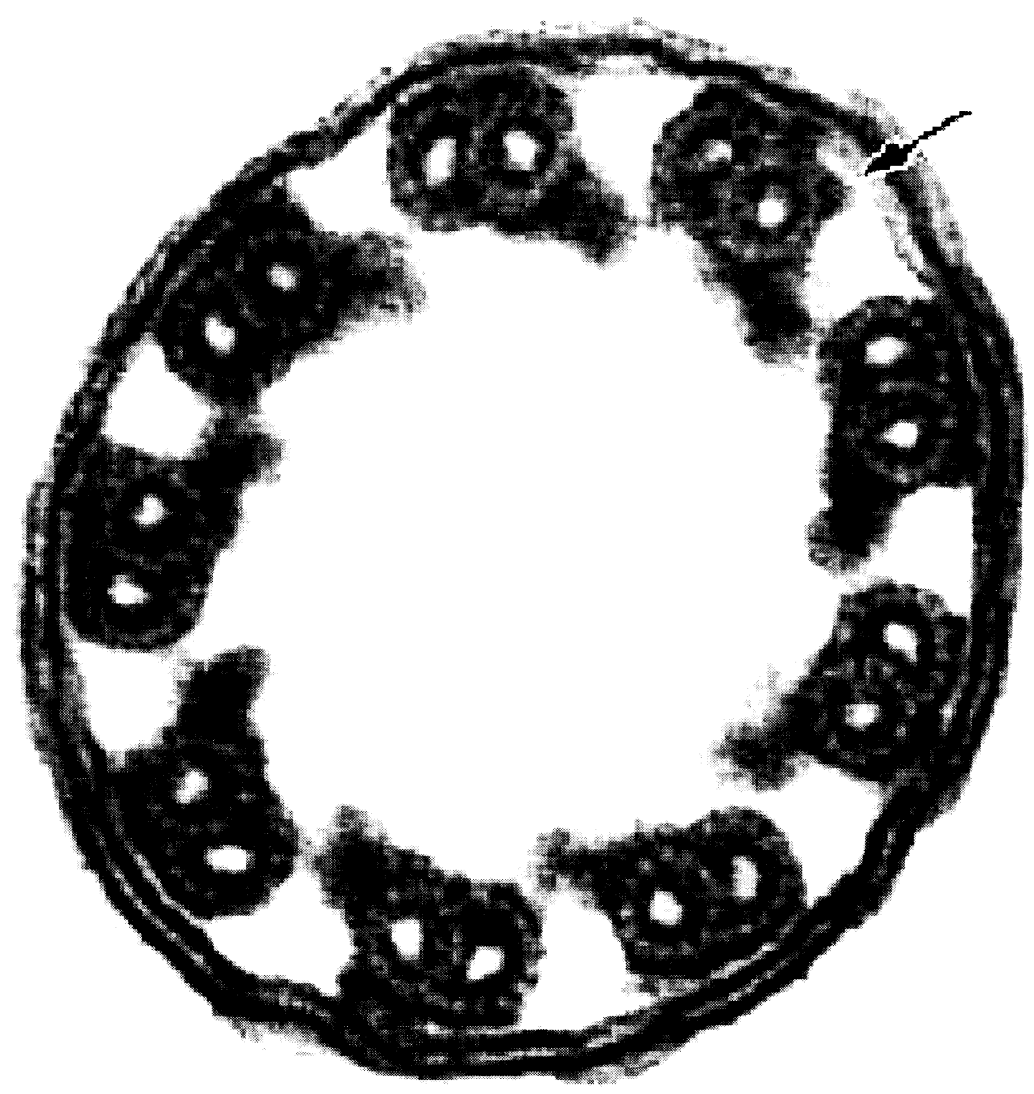

Rys. 3. Żywe przeciwieństwo „Nieredukowalnej Złożoności”.

Uwaga: przekrój wici plemnika węgorza. W innych organizmach, ta „nieredukowalnie złożona" struktura posiada centralną parę mikrotubul, szprychy łączące ją z zewnętrznymi dubletami oraz zewnętrzne ramiona dyneinowe łączące dublety. Wszystkich tych struktur brakuje w wici plemnika węgorza (strzałka pokazuje lokalizację jednego $\mathrm{z}$ brakujących ramion dyneinowych), a mimo to struktura ta jest $\mathrm{w}$ pełni funkcjonalna. Zaczerpnięte z: WoLLEY, „Studies on the eel sperm flagellum...”, s. 91. 
Biorąc pod uwagę te fakty, można zapytać, co jest jądrem argumentu na rzecz biochemicznego projektu - tego, że części nieredukowalnie złożonej struktury nie pełnią z osobna żadnej funkcji? Kluczowa część tego twierdzenia głosi, że „każdy prekursor systemu nieredukowalnie złożonego, któremu brakuje jakiejś części, jest z definicji niefunkcjonalny”. Ale pojedyncze składniki rzęski, łącznie z tubuliną, białkiem motorycznym (dyneiną) i białkiem kurczliwym (aktyną), są w pełni funkcjonalne w innym miejscu komórki. Oznacza to oczywiście, że każda z głównych części rzęski pełni swoją funkcję i dlatego ów argument jest niedobry.

\section{Baty i strzykawki}

„Wizytówką" nieredukowalnej złożoności była wić bakteryjna. W ujęciu wielu krytyków dobrze dopasowane części tego jonowo napędzanego silnika przedstawiają wyzwanie nie do przezwyciężenia dla ewolucjonizmu darwinowskiego. Jednak i tym razem szczegółowe zbadanie tego niesamowitego mechanizmu biochemicznego mówi nam zupełnie co innego.

Przede wszystkim, istnieje więcej niż jeden typ „wici bakteryjnej”. Wici znajdowane $\mathrm{w}$ archebakteriach wyraźnie nie są nieredukowalnie złożone. Ostatnie badania pokazały, że wiciowe białka tych organizmów są blisko spokrewnione $\mathrm{z}$ grupą białek, występujących na powierzchni komórek, znanych jako piliny Klasy IV. ${ }^{14}$ Skoro te białka mają dobrze określoną funkcję, która nie jest związana z ruchem, to archaiczne wici nie przechodzą pomyślnie testu na nieredukowalną złożoność.

Jest jasne, że gdy Behe mówi o wici bakteryjnej, to odnosi się do wici znajdowanej $\mathrm{w}$ eubakteriach. Rysunki wici eubakteryjnych

\footnotetext{
${ }^{14}$ K.F. JARREL, D.P. BAyley and A.S. Kostyukowa, „The archael flagellum: A unique motility structure”, Journal of Bacteriology 1996, vol. 178, s. 5,057-5,064.
} 
pojawiają się w Darwin's Black Box, ${ }^{15} \mathrm{dr}$ Behe użył ich również w wielu publicznych prezentacjach. Czy te struktury przechodzą pomyślnie test na nieredukowalną złożoność? Jak na ironię - nie.

W roku 1998 odkryto, że wici eubakterii są blisko związane z nie dotyczącym ruchu kompleksem błony komórkowej, znanym jako aparat wydzielinowy Typu III. ${ }^{16}$ Kompleksy te odgrywają śmiercionośną rolę w cytotoksycznych (niszczących komórkę) czynnościach bakterii, powodujących dymienicę morową, takich jak Yersinia pestis. Gdy te bakterie infekują organizm, komórki bakterii wiążą się z bakteriami żywiciela, a potem wstrzykują toksyny przez aparat wydzielinowy Typu III do cytoplazmy żywiciela. Wysiłki czynione dla zrozumienia śmiercionośnych skutków oddziaływania tych bakterii na ich żywicieli doprowadziły do molekularnych badań białek w aparacie Typu III i szybko stało się oczywiste, że co najmniej dziesięć z nich jest homologicznych względem białek, które tworzą część podstawy wici bakteryjnej. ${ }^{17}$

Oznacza to, że część przypominającej bat wici bakteryjnej działa jak „strzykawka”, którą stanowi aparat wydzielinowy Typu III. Innymi słowy, podzbiór białek jest w pełni funkcjonalny w zupełnie innym układzie - nie dotyczącym ruchu, lecz w kontekście śmiercionośnego dostarczania toksyn do komórki żywiciela. Obserwacja ta falsyfikuje główne twierdzenie biochemicznego argumentu z projektu - to mianowicie, że podzbiór części nieredukowalnie złożonej struktury musi być „z definicji niefunkcjonalny”. Mamy dziesięć białek z wici, którym brakuje nie tylko jednej, lecz więcej niż czterdziestu części, a mimo to są one w pełni funkcjonalne w aparacie Typu III.

\footnotetext{
${ }^{15}$ BeHE, Darwin's Black Box..., s. 71.

${ }^{16}$ C.J. HuECK, „Type III protein secretion systems in bacterial pathogens of animals and plants", Microbiology and Molecular Biology Review 1998, vol. 62, s. 379-433.

${ }^{17}$ Tamże, s. 410.
} 


\section{Obalenie hipotezy projektu}

Jeśli biochemiczny argument z projektu jest hipotezą naukową, jak twierdzą jego zwolennicy, to powinien dawać specyficzne, naukowo testowalne przewidywania. Najważniejsze przewidywanie hipotezy nieredukowalnej złożoności pokazano na rysunku 4 i mówi ono, że składniki struktur nieredukowalnie złożonych nie powinny pełnić funkcji, które może faworyzować dobór naturalny.

Jak widzieliśmy, podzbiór białek z wici pełni w rzeczywistości podatną na dobór funkcję w aparacie wydzielinowym Typu III. Możemy jednak sformułować ogólniejsze twierdzenie o wielu składnikach wici eubakteryjnej (zobacz rysunek 5). Białka stanowiące wić są blisko związane $\mathrm{z}$ różnorodnymi powierzchniowymi białkami komórki, łącznie $\mathrm{z}$ pilinami znajdowanymi u rozmaitych bakterii. Pewna część wici działa jako kanał jonowy, a kanały jonowe znajdują się we wszystkich bakteryjnych błonach komórkowych. Część podstawy wici uczestniczy w wydzielaniu białek i - ponownie - wszystkie bakterie posiadają systemy wydzielania białek związane $\mathrm{z}$ ich błoną komórkową. W końcu sercem wici jest jonowo napędzany silnik obrotowy, niezwykła maszyneria białkowa, która przekształca przepływ jonów w ruch obrotowy białek, umożliwiający wici poruszanie się. Czy ta część wici rzeczywiście musi być wyjątkowa? Wcale nie. Wszystkie bakterie posiadają kompleks białek błonowych, znany jako syntaza ATP, który wykorzystuje przepływ jonów do produkcji ATP. Jak działa ta syntaza? Wykorzystuje ona energię przepływu jonów do produkcji ruchu obrotowego. Krótko mówiąc, co najmniej cztery kluczowe elementy wici eubakteryjnej pełnią w komórce inne podatne na dobór funkcje, które nie są związane z jej ruchem. 

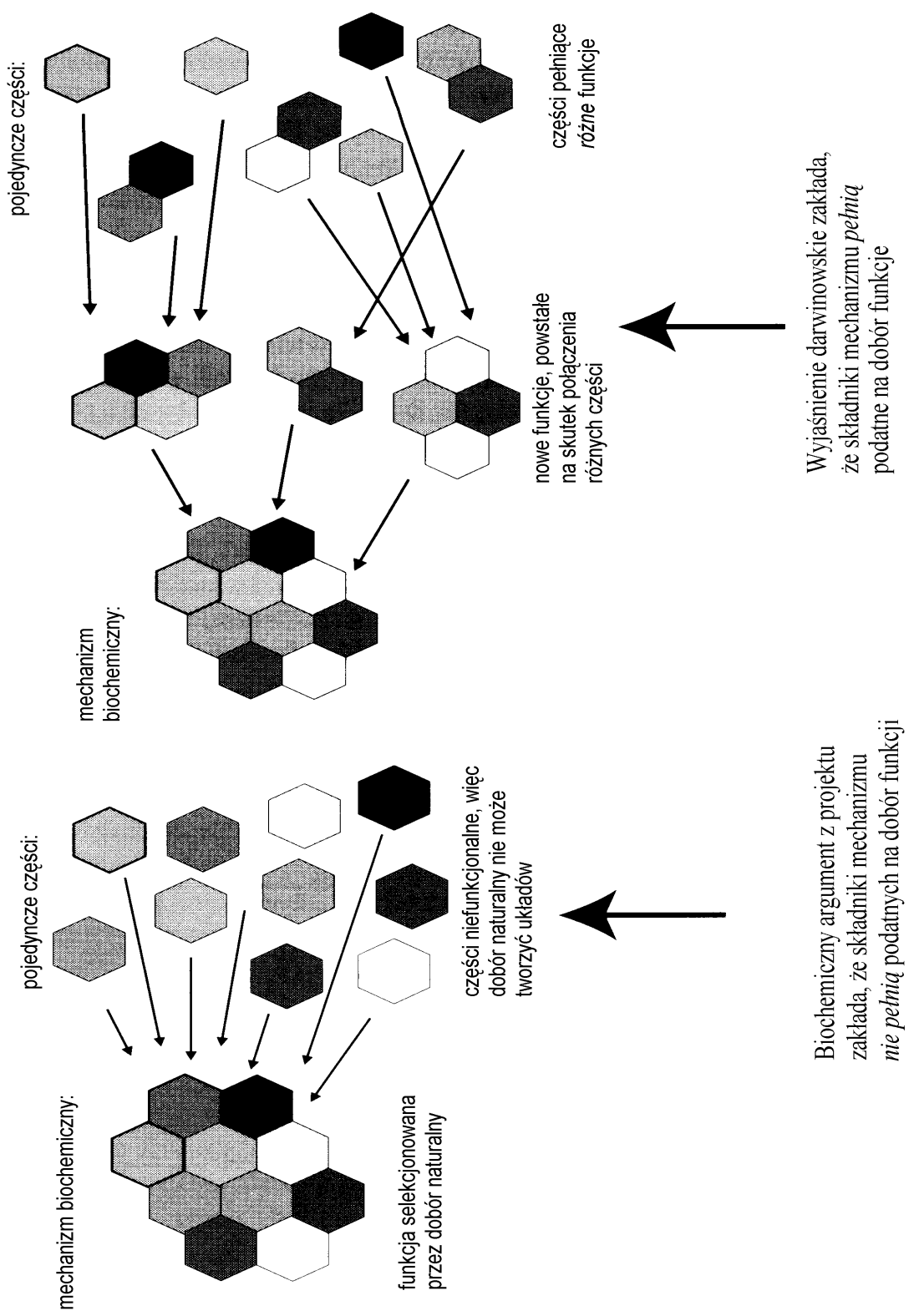
Fakty te ukazują, że system, najczęściej przytaczany jako pierwszorzędny przykład nieredukowalnej złożoności, posiada pojedyncze części, które pełnią podatne na dobór funkcje. W kategoriach naukowych oznacza to, że hipoteza nieredukowalnej złożoności została sfalsyfikowana. Jednakże te same fakty popierają darwinowskie wyjaśnienie systemów złożonych.

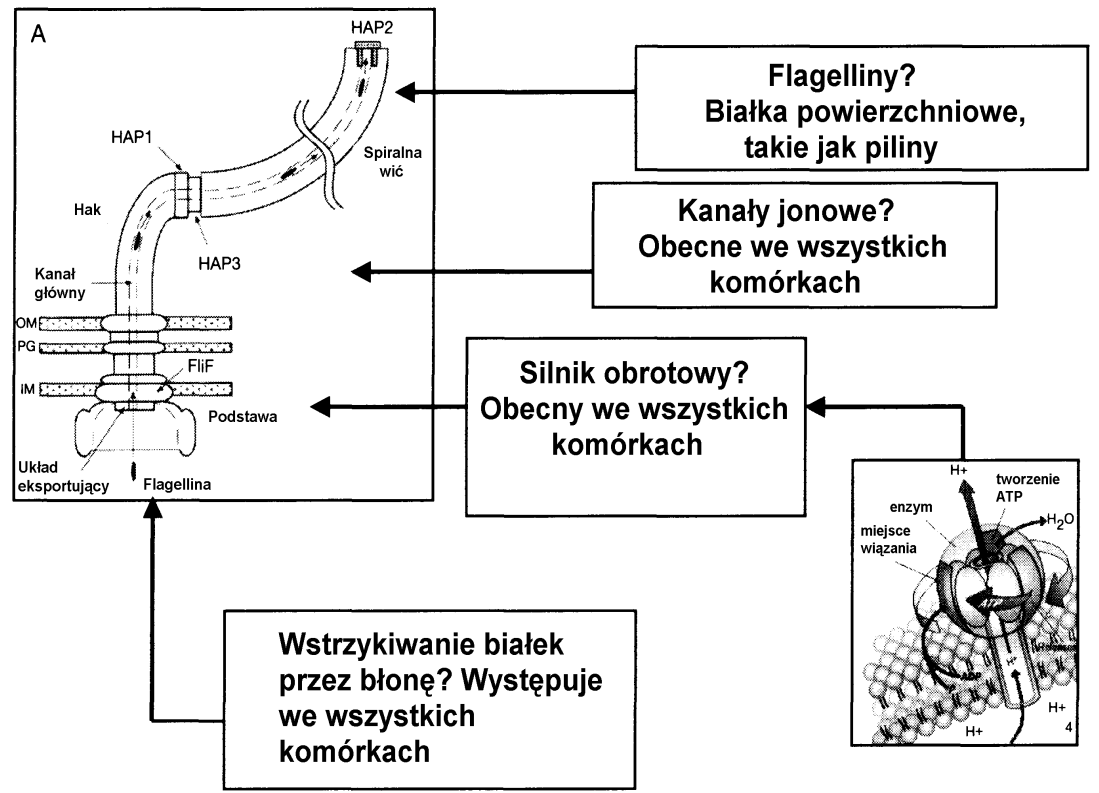

Rys. 5. Redukowalna wić.

Uwaga: co najmniej cztery składniki wici eubakteryjnej pełnią podatne na dobór funkcje, które nie są związane z ruchem.

Można oczywiście postawić zarzut, że nie dostarczyłem szczegółowego, stopniowego wyjaśnienia ewolucji wici. Czy bowiem takie wyjaśnienie nie jest potrzebne do unieważnienia biochemicznego argumentu z projektu? 
Krótko mówiąc - nie. Nie, chyba że argument ten zredukuje się do samego spostrzeżenia, że brakuje jeszcze ewolucyjnego wyjaśnienia wici eubakteryjnej. Mógłbym się zgodzić z takim twierdzeniem. Jednakże spór wszczęty przez Behe'ego dotyczy czegoś zupełnie innego - tego mianowicie, że ewolucja nie może $w$ zasadzie wyjaśnić pochodzenia wici (ponieważ jej liczne składniki nie pełnią żadnej podatnej na dobór funkcji). Dzięki pokazaniu istnienia takich funkcji, nawet tylko w przypadku garstki składników, unieważniliśmy ten argument.

\section{Zlapany w pulapkę na myszy}

Dlaczego biochemiczny argument z projektu upadł tak szybko po przeprowadzeniu szczegółowego sprawdzenia? Sądzę, że stało się tak z powodu wadliwości samej logiki tego argumentu. Rozważmy na przykład mechaniczną pułapkę na myszy jako analogię układów nieredukowalnie złożonych. Behe napisał, że pułapka na myszy nie będzie działać, jeśli usunie się choćby jedną z jej pięciu części. Jednakże przy odrobinie pomysłowości okazuje się, że niezwykle łatwo skonstruować działającą pułapkę na myszy po usunięciu jednej z jej części, zostawiając tylko cztery. W rzeczywistości profesor McDonald z University of Delaware poszedł jeszcze dalej, umieszczając na stronie internetowej rysunki, które ukazują, jak można skonstruować pułapkę na myszy z trzema, dwiema czy tylko jedną częścią. Mcdonaldowskie projekty pułapek na myszy są dostępne pod adresem internetowym: http://udel.edu/ modonald/mousetrap.html.

Behe zareagował na te prostsze pułapki na myszy całkiem poprawnie, wykazując, że do ich zbudowania potrzebne są interwencja i pomysłowość ludzka i dlatego nie prezentują one niczego, co byłoby bliskie modelowi „ewolucji” pułapki pięcioczęściowej. Przeocza on jednak decydującą kwestię: czy podzbiory pułapki pięcioczęściowej są przydatne (pełnią osobną funkcję) w różnych kontekstach? Rozważmy następujące przykłady: dla osobistego użytku noszę czasem spinkę do 
krawata składającą się z tylko trzech części (podstawy, sprężyny i młoteczka) i łańcuszek na klucze składający się z tylko dwóch (podstawy i młoteczka). W rzeczywistości można wyobrazić sobie mnóstwo zastosowań dla części „nieredukowalnie złożonej” pułapki na myszy, niektóre z nich wymieniono na rysunku 6.

Pojedyncze części rzekomo nieredukowalnie złożonego mechanizmu są w pełni funkcjonalne dla różnych celów. Przykłady: spinka do krawata (3); kółko na klucze (2); przycisk na lodówkę (3+1); podkładka pod notatki (2); kołatka do drzwi (3); przycisk do papierów (1); drewno na podpałkę (1); katapulta (4); dziadek do orzechów (3); kolczyk do nosa (2); haczyk na ryby (1); wykałaczka (1).

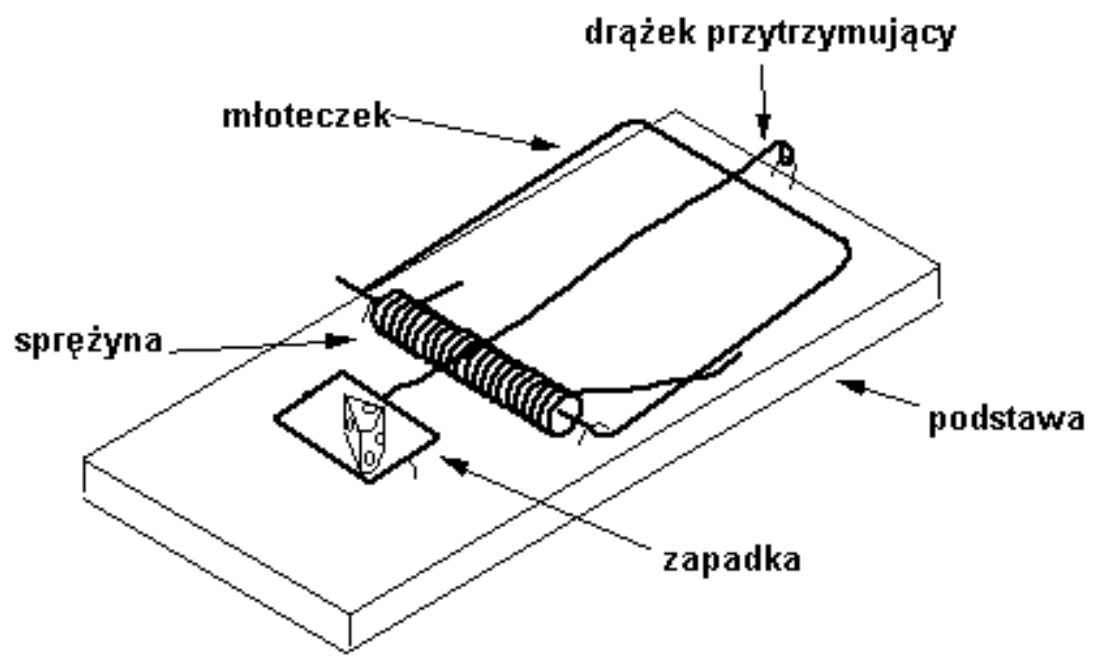

Rys. 6. Redukowalna pułapka na myszy.

Uwaga: istnieją zamienne funkcje różnych zestawów utworzonych z części standardowej, pięcioczęściowej pułapki na myszy. Liczby w nawiasach wskazują na liczbę części wymaganych dla każdej funkcji. Na przykład, aby uzyskać wykałaczkę potrzeba tylko jednej części (drążka przytrzymującego). Trzech części potrzeba, aby otrzymać spinkę (podstawy, sprężyny i młoteczka). Zacisk na lodówkę można sporządzić z tych samych trzech części oraz dodając jeszcze jedną część (magnes). 
Znaczenie powyższych rozważań powinno być jasne. Jeśli części domniemanej nieredukowalnie złożonej mechanicznej struktury są $\mathrm{w}$ pełni funkcjonalne w różnych kontekstach, to główne twierdzenie zbudowane na tym pojęciu jest niepoprawne. Jeśli części jakiegoś mechanizmu pełnią różne funkcje, znaczy to, że dobór naturalny faktycznie mógłby wytworzyć elementy mechanizmu biochemicznego dla różnych celów. Przykład pułapki na myszy niechcący dostarcza doskonałej analogii dla sposobu, w jaki dobór naturalny buduje złożone struktury.

\section{Zerwanie lańcucha}

Krytycy ewolucjonizmu naiwnie twierdzą, że „odkryli” świadectwo empiryczne na rzecz inteligentnego projektu w systemach biochemicznych, sugerując, że znaleźli pozytywne świadectwo działania projektanta. Sam Behe używa takiego języka, pisząc:

Rezultatem tych łącznych wysiłków badania komórki - badania życia na poziomie molekularnym - jest głośne, wyraźne, przeszywające wołanie o projekt! Jest to rezultat tak niedwuznaczny i znaczący, że musi zostać zaliczony do największych osiągnięć w historii nauki. Odkrycie to rywalizuje z odkryciami Newtona i Einsteina, Lavoisiera i Schrödingera, Pasteura i Darwina. ${ }^{18}$

Jakie właściwie jest źródło tego „głośnego, przeszywającego wołania"? Okazuje się, że nie ma żadnego bezpośredniego świadectwa empirycznego, a raczej łańcuch rozumowania - zaczynający się od zaobserwowania „nieredukowalnej złożoności” i prowadzący krok po kroku do wniosku o projekcie (zobacz poniżej) - któremu daleko do świadectwa doświadczalnego:

\footnotetext{
${ }^{18}$ BEHE, Darwin's Black Box..., s. 232-233.
} 
Jakie jest „świadectwo empiryczne” na rzecz projektu?

Przedstawiono tu logiczny łańcuch rozumowania prowadzący od zaobserwowania biochemicznej złożoności do wniosku o inteligentnym projekcie.

1. Obserwacja: komórka zawiera mechanizmy biochemiczne, w których strata jakiegoś jednego składnika może znieść ich funkcję. Definicja: dlatego mówi się, że takie mechanizmy są ,nieredukowalnie złożone".

$\Downarrow$

2. Zapewnienie: każda nieredukowalnie złożona struktura, której brakuje jakiejś części, jest $\mathrm{z}$ definicji niefunkcjonalna, pozbawiając dobór naturalny tego, co mógłby selekcjonować.

3. Wniosek: dobór naturalny nie mógłby więc wytworzyć struktur nieredukowalnie złożonych.

$\Downarrow$

4. Wniosek drugi: takie struktury musiał dlatego wytworzyć inny mechanizm. Skoro jedynym wiarygodnym, alternatywnym mechanizmem jest inteligentny projekt, to właśnie istnienie takich struktur musi świadczyć na rzecz inteligentnego projektu.

Gdy tak rozkłada się rozumowanie ukryte za biochemicznym argumentem z projektu, łatwo zauważyć jego logiczną wadę. Pierwsze twierdzenie jest prawdziwe - komórka faktycznie zawiera dowolną ilość złożonych mechanizmów molekularnych, w których strata jakiejś jednej części może wpłynąć na ich funkcjonowanie. Można jednak do- 
wieść, że drugie twierdzenie - zapewnienie o niefunkcjonalności - jest fałszywe. Jak widzieliśmy, pojedyncze części wielu takich mechanizmów naprawdę pełnią w komórce dobrze określone funkcje. Gdy zdamy sobie z tego sprawę, upadnie logika tego argumentu. Skoro wykazano, że zapewnienie $\mathrm{w}$ punkcie 2 jest fałszywe, to łańcuch rozumowania zostaje zerwany, a oba wnioski są błędne.

Komórka nie zawiera biochemicznego świadectwa na rzecz projektu.

\section{Duch Paleya}

Następcy Paleya w dwudziestym pierwszym wieku twierdzą, że ruch ID bazuje na nowych odkryciach w biologii molekularnej i reprezentuje nowatorski ruch naukowy, który zasługuje, by zwrócić nań naukową i edukacyjną uwagę. W wyrażonym we współczesnym języku biochemii sformułowaniu przez Behe'ego tez Paleya ruch ten pokłada największą nadzieję na to, że jego poglądy zostaną uznane jako naukowo uzasadnione. Jednakże, jak zobaczyliśmy w tym krótkim przeglądzie, nadzwyczaj łatwo jest odrzucić każde z jego głównych twierdzeń.

Analiza ta pokazuje, że „świadectwo empiryczne”, stosowane przez współczesnych zwolenników inteligentnego projektu w celu wskrzeszenia dziewiętnastowiecznych argumentów Paleya, nie jest ani nowatorskie, ani nowe. W rzeczywistości jedynym twierdzeniem przeciwko darwinizmowi, jakie im pozostało, jest to, że oni nie moga sobie wyobrazić, w jaki sposób ewolucja mogła wytworzyć takie systemy. Wielokrotnie inni naukowcy, nie zrażeni takim pesymizmem, pokazali (i opublikowali) przeciwne wyjaśnienia. Nawet zastosowanie przez ten ruch poszczególnych mechanizmów jako przykładów „,nieredukowalnej złożoności” okazuje się nieprawidłowe, gdy dokładnie je zbadać. Ostatecznie sama logika argumentu ma oczywistą i fatalną wadę. 
Behe tak argumentuje, że powodem oporu społeczności naukowców przed wyjaśnieniem z projektu jest antyreligijne uprzedzenie:

Dlaczego społeczność naukowców nie przyjmuje chętnie swego zaskakującego odkrycia? Dlaczego obserwuje projekt z klapkami na oczach? Dylemat polega na tym, że gdy do jednej strony słonia przyczepi się etykietkę inteligentnego projektu, to do jego drugiej strony można przyczepić etykietkę Boga. ${ }^{19}$

Myślę, że rzeczywisty powód jest znacznie prostszy. Społeczność naukowców nie przyjęła wyjaśnienia z projektu, ponieważ świadectwa empiryczne wskazują zupełnie jasno, że jest ono niedobre.

Kenneth R. Miller

${ }^{19}$ Tamże, s. 232. 